\title{
Lignin-Degrading Abilities of Novel Autochthonous Fungal Isolates Trametes hirsuta F13 and Stereum gausapatum F28
}

\author{
Jelena Jović*, Aneta \\ Buntić, Neda Radovanović, \\ Bojan Petrović and \\ Ljiljana Mojović
}

University of Belgrade, Faculty of Technology and Metallurgy, Department for Biochemical Engineering and Biotechnology, Karnegijeva 4, RS-11120 Belgrade, Serbia

Received: 18 May 2017 Accepted: 26 March 2018
*Corresponding author:

Phone: +381628766059;

E-mail:yowitch@gmx.com

\begin{abstract}
SUMMARY
The aim of this research is to isolate and identify fungi with high lignin-degrading abilities that are autochthonous to southern Serbian region. Two novel fungal isolates identified as Trametes hirsuta F13 and Stereum gausapatum F28 were selected to assess their ligninolytic enzyme activities and the efficiency of lignin removal from beech wood sawdust. Obtained results show that both isolates are good sources of industrially valuable enzymes with a potential for application in various biotechnological and industrial processes. Both isolates showed laccase, manganese-dependent peroxidase, and versatile peroxidase activities, while only S. gausapatum F28 had lignin peroxidase activity. This is the first record of the ability of $S$. gausapatum species to produce lignin peroxidase. T. hirsuta F13 showed higher laccase activity than S. gausapatum F28, while S. gausapatum F28 had higher manganese peroxidase activity. Also, T. hirsuta F13 exhibited much higher laccase activity under submerged cultivation conditions than solid-state cultivation conditions, which is rare for fungi. This is important for industrial processes since the submerged fermentation is a dominant technique in industry. The test of the efficiency of lignin removal showed that both isolates are efficient lignin decomposers. After five weeks of incubation on beech wood sawdust, the total lignin losses were $33.84 \%$ with T. hirsuta F13 and $28.8 \%$ with S. gausapatum F28.
\end{abstract}

Key words: Trametes hirsuta, laccase, manganese peroxidase, Stereum gausapatum, lignin removal, white-rot fungi

\section{INTRODUCTION}

During the course of evolution, fungi have developed mechanisms to access energy incorporated in recalcitrant plant biomass in the form of polysaccharides. These mechanisms are based on the activity of various enzymes capable of breaking inter- and intrapolymer bonds of the lignocellulosic substrate, thus releasing fermentable sugars. According to the type of enzymatic activity required for a bond cleavage, lignocellulose-degrading mechanisms form two groups: hydrolytic and oxidative. Hydrolytic enzymes (cellulase and hemicellulases) break glycosidic bonds ( $\beta-1,4-, \beta-1,3-, \beta-1,2-$ and $\beta-1,6-)$ that connect subunits of lignocellulose polysaccharides. Lignin subunits are mainly linked by ether-like or carbon-carbon bonds that cannot be hydrolyzed (1). Its degradation occurs through oxidative processes catalyzed by fungal enzymes which include: manganese-dependent peroxidase (MnP, EC 1.11.1.13), lignin peroxidase (LiP, EC 1.11.1.14), versatile peroxidase (VP, manganese-independent peroxidase, EC 1.11.1.16) and laccase (benzenediol:oxygen oxidoreductase, EC 1.10.3.2) (2).

Being the most effective decomposers of lignocellulosic materials, filamentous fungi have attracted attention in the past few decades for extensive examination for applications in biorefinery and various industrial processes. The use of agricultural or other types of lignocellulosic waste for the production of biofuels or other useful fermentable products is hindered by its recalcitrance towards microorganisms and their enzymes (3). Finding an efficient and inexpensive method for lignin removal is one of the primary objectives in the exploitation of lignocellulosic waste. Use of wood-decay fungi for lignin removal is an attractive method because it does not require additional energy and toxic chemicals, and 
generates no hazardous by-products. The wood-decay fungi and their ligninolytic mechanisms are also interesting for the removal of heavy metals and toxic compounds from polluted water and soil (4-6). It has been proven that they can transform toxic organic chemicals (PCDDs, PAHs, PCBs) to less harmful or harmless forms (7-11). Fungal enzymes can also degrade recalcitrant azo dyes (which make about $70 \%$ of all industrial dyes) and pesticides (e.g. DDT, lindane and widely used herbicide glyphosate) (12-14).

Over the last decade, the frequency of reported new wood-decomposing fungal strains has grown. Search for better lignin-degrading systems encouraged the study of fungi native to different geographical regions and adapted to different climate types. Efficient lignin-degrading mechanisms offer more ecologically and economically favourable alternative solutions for different biotechnological and/or agricultural processes (15). Besides the global impact, the use of indigenous strains has advantages at the local level as well, since it preserves autochthonous fungal flora, and is expected to remove autochthonous lignocellulosic waste more efficiently than commercial strains.

There is not much information about lignin-degrading systems of fungi that are autochthonous to Serbia. So far, there has been only data on ligninolytic abilities of few species from genera Trametes and Ganoderma (16-19) collected in the central and western territory (the area of Belgrade and Loznica, respectively).

The aim of this research is to isolate and identify novel fungi with high lignin-degrading ability autochthonous to southern parts of Serbia. The focus of this paper is on two isolates, Trametes hirsuta F13 and Stereum gausapatum F28, collected in the area of the city of Leskovac and identified according to their morphological and molecular characteristics. Evaluation of ligninolytic abilities of fungal isolates included an examination of the activities of ligninolytic enzymes and lignin removal from beech wood sawdust, which served as a model for lignocellulosic material.

\section{MATERIALS AND METHODS}

\section{Chemicals}

A local sawmill, located in the village of Strojkovce, 12 $\mathrm{km}$ south of the City of Leskovac, Serbia (N 4254'10.976", E $\left.21^{\circ} 55^{\prime} 7.658^{\prime \prime}\right)$, provided beech wood sawdust. Reagents for detection of enzyme activities were: guaiacol (99\%; ACROS Organics, Thermo Fisher Scientific, Fair Lawn, NJ, USA), Azure B ( $\geq 89 \%$, certified by the Biological Stain Commission; Sigma-Aldrich, Merck, St. Louis, MO, USA) and phenol red (Merck, Darmstadt, Germany). Chemicals for preparation of buffers were: tartaric acid ((+)-tartaric acid, extra pure, SLR, crystals; Fisher Chemical, Fisher Scientific, Loughborough, UK), sodium lactate (solution, extra pure, SLR; Fisher Chemical, Fisher Scientific), lactic acid (DL-lactic acid approx. 90 \%; Sigma-Aldrich, Merck, Steinheim, Germany) and sodium acetate (anhydrous, laboratory reagent grade; Fisher Chemical, Fisher Scientific).
Other chemicals were: hexadecyltrimethylammonium bromide (CTAB; for molecular biology, $\geq 99 \%$ ) and $\beta$-mercaptoethanol, (>99\%), both from Sigma-Aldrich, Merck, Steinheim, Germany.

\section{Isolation and maintenance of fungi}

Two fungi, collected from an oak forest and orchard near the forest on a hill in the area of the city of Leskovac (in southern Serbia), were under investigation for lignocellulolytic activity. Details of the locality where they were collected are in Table 1. A surface sterilization technique with $70 \%$ ethanol was used for isolation of fungal cultures from fruiting bodies. Fungi were isolated onto potato dextrose agar (PDA; preparation of one litre required: $20 \mathrm{~g}$ dextrose, $15 \mathrm{~g}$ agar and $200 \mathrm{~g}$ potatoes, boiled for $30 \mathrm{~min}$ and then filtered through two layers of cheesecloth; $\mathrm{pH}=6.2$ ). After mycelium formation, small pieces from the edges of the actively growing fungus were transferred to a fresh agar every 3-5 days until a pure culture was obtained. Purified cultures were maintained at $30^{\circ} \mathrm{C}$ on PDA and transferred to fresh agar every $2-3$ weeks, to be prepared for immediate use. The stocks were prepared and stored at $4{ }^{\circ} \mathrm{C}$ on PDA slants and transferred to a fresh slant agar once every six months.

Table 1. Details of the location where the fungi were collected

\begin{tabular}{|c|c|c|}
\hline \multirow[b]{2}{*}{ Locality } & \multicolumn{2}{|c|}{ Fungal isolate } \\
\hline & $\begin{array}{c}\text { Trametes } \\
\text { hirsuta F13 }\end{array}$ & $\begin{array}{c}\text { Stereum } \\
\text { gausapatum F28 }\end{array}$ \\
\hline Isolation source & Cherry wood branch & Oak wood branch \\
\hline Host & Prunus cerasus & Quercus sp. \\
\hline Locality & $\begin{array}{c}\text { Area of Leskovac, } \\
\text { Serbia }\end{array}$ & $\begin{array}{c}\text { Area of Leskovac, } \\
\text { Serbia }\end{array}$ \\
\hline GPS coordinates & $\begin{array}{l}\text { N } 43^{\circ} 4^{\prime} 0.871^{\prime \prime} \\
\text { E } 21^{\circ} 54^{\prime} 6.056^{\prime \prime}\end{array}$ & $\begin{array}{l}\text { N } 43^{\circ} 4^{\prime} 1.831^{\prime \prime} \\
\text { E } 21^{\circ} 54^{\prime} 6.21^{\prime \prime}\end{array}$ \\
\hline Altitude & $325 \mathrm{~m}$ & $325 \mathrm{~m}$ \\
\hline Season & Winter & Spring \\
\hline Collection date & 6 January 2014 & 5 June 2014 \\
\hline $\begin{array}{l}\text { Daily temperature } \\
\text { range on the day of } \\
\text { sample collection }\end{array}$ & $12-16^{\circ} \mathrm{C}$ & $25-28^{\circ} \mathrm{C}$ \\
\hline
\end{tabular}

\section{Inoculum preparation and cultivation conditions}

An agar disc of $10 \mathrm{~mm}$ in diameter was taken from the edge of the actively growing culture of each purified isolate, aseptically transferred to inoculum agar medium, and subsequently incubated at $30^{\circ} \mathrm{C}$, in the dark, for 7 days. Agar medium used for inoculum preparation consisted of (in $\mathrm{g} / \mathrm{L}$ ): $\mathrm{NH}_{4} \mathrm{NO}_{3}$ 2.0, yeast extract 1.0, glucose 10.0, $\mathrm{KH}_{2} \mathrm{PO}_{4} 1.0, \mathrm{MgSO}_{4} \cdot 7 \mathrm{H}_{2} \mathrm{O} 0.5$, $\mathrm{CaCl}_{2} \cdot 2 \mathrm{H}_{2} \mathrm{O} 0.01$ and agar 15.0. Prior to sterilization, the $\mathrm{pH}$ was adjusted to 5.5. Six agar discs (10 $\mathrm{mm}$ in diameter) were cut from the edge of actively growing cultures and aseptically transferred to the substrate for enzyme production. Equal amount of inoculum was used for the inoculation of solid and liquid substrates. In qualitative analysis, Petri plates were inoculated with one agar disc placed in the middle. 


\section{Qualitative analysis of enzyme activity}

Lignin-modifying enzyme basal medium (LBM) was prepared according to Pointing protocols (20), with $\mathrm{NH}_{4} \mathrm{NO}_{3}$ instead of ammonium tartrate. The $\mathrm{pH}$ was adjusted to 5.5. Lignin-modifying enzymes were assayed on LBM supplemented with $0.05 \%$ (by mass per volume) guaiacol and 0.005 $\%$ (by mass per volume) a-naphthol for laccase activity, and $0.01 \%$ (by mass per volume) Azure B for peroxidase activity. The guaiacol and Azure B were added prior to sterilization to the appropriate basal medium, while a-naphthol was added after sterilization, prior to use. The qualitative assay was performed in Petri dishes $90 \mathrm{~mm}$ in diameter.

\section{Substrates for quantitative analysis}

Screening for ligninolytic enzymes

Enzymes were produced on beech wood sawdust supplemented with a mineral medium for ligninolytic enzyme production (LMM) (21). LMM consisted of (in $\mathrm{g} / \mathrm{L}$ ): $\mathrm{NH}_{4} \mathrm{NO}_{3}$ $0.5, \mathrm{KH}_{2} \mathrm{PO}_{4} 1.0, \mathrm{MgSO}_{4} \cdot 7 \mathrm{H}_{2} \mathrm{O} 0.5$, yeast extract $1.0, \mathrm{CaCl}_{2} \cdot 2 \mathrm{H}_{2} \mathrm{O}$ $0.01, \mathrm{CuSO}_{4} \cdot 5 \mathrm{H}_{2} \mathrm{O} 0.05, \mathrm{MnSO}_{4} \cdot \mathrm{H}_{2} \mathrm{O} 0.03, \mathrm{FeSO}_{4} \cdot 7 \mathrm{H}_{2} \mathrm{O} 0.05, \mathrm{Zn}-$ $\mathrm{SO}_{4} \cdot 7 \mathrm{H}_{2} \mathrm{O} 0.035$ and $\mathrm{CoCl}_{2} \cdot 6 \mathrm{H}_{2} \mathrm{O} 0.02$. The $\mathrm{pH}$ value was adjusted to 5.5 prior to sterilization. Solid-state fermentation (SSF) was carried out in the dark, at $30^{\circ} \mathrm{C}$, in $100-\mathrm{mL}$ Erlenmeyer flasks that contained $5 \mathrm{~g}$ beech wood sawdust as a carbon source and $9 \mathrm{~mL}$ mineral medium (70\% substrate humidity). Submerged fermentation (SF) was carried out under static conditions, also in the dark at $30{ }^{\circ} \mathrm{C}$, in 300-mL Erlenmeyer flasks loaded with $3 \mathrm{~g}$ sawdust and $50 \mathrm{~mL}$ LMM. All fermentations were performed in duplicates. Prior to inoculation, the substrates were sterilized in an autoclave for $30 \mathrm{~min}$.

\section{Testing of the moisture effect on enzyme activity}

Sawdust supplemented with LMM of the same composition as that used for screening process (see the previous chapter) was used to test the effect of substrate moisture on ligninolytic enzyme activity. Two different moisture contents were used: 68 and $75 \%$. The activities were tested on the seventh day of incubation.

Time course of ligninolytic enzyme activity and protein production on a simple substrate

The ability of selected fungi to produce ligninolytic enzymes on a simple solid substrate (SSdS) was tested on beech wood sawdust with added $\mathrm{dH}_{2} \mathrm{O}$. During ten days of incubation, laccase and manganese-dependent peroxidase (MnP) activities were measured on the third, fifth, seventh and tenth day. The activities were compared to the enzyme activities obtained on beech wood sawdust supplemented with LMM (lignocellulose-mineral substrate, LMS). Total moisture content of both substrates was adjusted to $75 \%$.

\section{Extraction of secreted enzymes}

Enzymes produced in SSF were extracted with $50 \mathrm{~mL}$ of distilled water. Water was added to Erlenmeyer flasks and subsequently shaken for $30 \mathrm{~min}$ at $220 \mathrm{rpm}$ and $30^{\circ} \mathrm{C}$. The liquid phase was separated from the solid phase by filtration through Whatman no. 1 filter paper at $4{ }^{\circ} \mathrm{C}$ and centrifugation at $4185 \times g$ at $(25 \pm 2)^{\circ} \mathrm{C}$ using Z $206 \mathrm{~A}$ high capacity, compact centrifuge (HERMLE Labortechnik GmbH, Wehingen, Germany). SF went through the same separation process. The extracts were stored at $4{ }^{\circ} \mathrm{C}$ until use. Enzyme activity assays were performed within $24 \mathrm{~h}$ of the extraction.

\section{Enzyme activity assays}

Enzyme activity was calculated by the following formula:

$$
\mathrm{EA}=(\Delta A \cdot V) /(t \cdot \varepsilon \cdot V \cdot d)
$$

where $E A$ is enzyme activity $(\mathrm{U} / \mathrm{mL}), \Delta A$ is absorbance change, $V$ is reaction mixture volume $(\mathrm{mL}), t$ is incubation time $(\mathrm{min})$, $\varepsilon$ is molar absorption coefficient $(\mathrm{L} /(\mathrm{mmol} \cdot \mathrm{cm})), v$ is enzyme extract/filtrate volume $(\mathrm{mL})$ and $d$ is cuvette length $(1 \mathrm{~cm})$. Where appropriate, enzymes were properly diluted and the dilution factor was included in the formula. One unit $(U)$ of enzyme activity was expressed as the amount of enzyme that catalyzes the oxidation of $1 \mu \mathrm{mol}$ of substrate per min.

The absorbance was measured with UV/Visible spectrophotometer (Ultrospec 3300 pro; Amersham Biosciences Ltd, Little Chalfont, UK). All measurements were done in triplicates.

Enzyme activity per unit of dry substrate mass $(\mathrm{U} / \mathrm{g})$ was calculated by the formula:

$$
\mathrm{EAM}=\left(\mathrm{EA} \cdot V_{\mathrm{ex}}\right) / m_{\mathrm{s}}
$$

where EAM is enzyme activity on solid substrate basis $(\mathrm{U} / \mathrm{g})$, EA is enzyme activity $(\mathrm{U} / \mathrm{mL}), V_{\text {ex }}$ is total volume of extracted enzymes $(\mathrm{mL})$, and $m_{\mathrm{s}}$ is dry mass of substrate $(\mathrm{g})$.

Specific enzyme activity was calculated by the formula:

$$
\mathrm{SEA}=\mathrm{EA} / \gamma
$$

where SEA is specific enzyme activity on protein basis (U/ $\mathrm{mg}), \mathrm{EA}$ is enzyme activity $(\mathrm{U} / \mathrm{mL})$, and $\gamma$ is protein mass concentration $(\mathrm{mg} / \mathrm{mL})$.

\section{Laccase activity assay}

Oxidation of guaiacol was used to determine laccase activity. A volume of $5 \mathrm{~mL}$ of the reaction mixture that contained $3 \mathrm{~mL}$ of $10 \mathrm{mmol} / \mathrm{L}$ sodium-acetate buffer ( $\mathrm{pH}=5), 1 \mathrm{~mL}$ of $2 \mathrm{mmol} / \mathrm{L}$ guaiacol and $1 \mathrm{~mL}$ of enzyme source was incubated at $30{ }^{\circ} \mathrm{C}$ for $15 \mathrm{~min}$. The absorbance of oxidized guaiacol was measured at $470 \mathrm{~nm}$ against reference mixture that contained water instead of guaiacol. Molar absorption coefficient used for guaiacol was $\varepsilon_{470 \mathrm{~nm}}=6.74 \mathrm{~L} /(\mathrm{mmol} \cdot \mathrm{cm})$ as reported by Hosoya (22). 


\section{Manganese peroxidase activity assay}

Determination of manganese peroxidase activity was based on oxidation of phenol red $(23,24)$. A volume of $5 \mathrm{~mL}$ reaction mixture contained: $1 \mathrm{~mL}$ sodium succinate buffer (50 mmol/L, $\mathrm{pH}=4.5), 0.7 \mathrm{~mL}$ phenol red $(0.1 \mathrm{mmol} / \mathrm{L}), 0.4$ $\mathrm{mL} \mathrm{MnSO}_{4}(0.1 \mathrm{mmol} / \mathrm{L}), 1.0 \mathrm{~mL}$ sodium lactate buffer (50 $\mathrm{mmol} / \mathrm{L}, \mathrm{pH}=4.5), 1.0 \mathrm{~mL}$ gelatin $(0.02 \%$ by mass per volume) and $0.5 \mathrm{~mL}$ enzyme extract. The reaction started with the addition of $0.4 \mathrm{~mL} \mathrm{H}_{2} \mathrm{O}_{2}(0.62 \mathrm{mmol} / \mathrm{L})$ to the reaction mixture. Control assay without $\mathrm{H}_{2} \mathrm{O}_{2}$ and test with $\mathrm{H}_{2} \mathrm{O}_{2}$ but without $\mathrm{Mn}^{2+}$ were also carried out. After 5 min of incubation at $(25 \pm 2){ }^{\circ} \mathrm{C}$, the reaction was stopped with $200 \mu \mathrm{L} 5 \mathrm{M} \mathrm{NaOH}$. The absorbance was measured against reference mixture that contained inactivated enzyme (enzyme extract boiled for $15 \mathrm{~min}$ at $100^{\circ} \mathrm{C}$ ) instead of the active one, at $610 \mathrm{~nm}$ (molar absorption coefficient used for oxidized phenol red was $\left.\varepsilon_{610 \mathrm{~nm}}=22 \mathrm{~L} /(\mathrm{mmol} \cdot \mathrm{cm})\right)$. For determination of total manganese peroxidase activity (MP), the activity of control was subtracted from the activity of reaction mixture with $\mathrm{H}_{2} \mathrm{O}_{2}$. For determination of manganese-dependent peroxidase activity $(\mathrm{MnP})$, the activity of mixture without $\mathrm{Mn}^{2+}$ was subtracted from the activity of mixture with $\mathrm{H}_{2} \mathrm{O}_{2}$. To determine versatile peroxidase activity (VP), the activity of control was subtracted from the activity of mixture without $\mathrm{Mn}^{2+}$.

\section{Lignin peroxidase activity assay}

Lignin peroxidase assay was performed according to the procedure proposed by Archibald et al. (25) and Arora and Gill (26). A volume of $2.5 \mathrm{~mL}$ reaction mixture contained: $1 \mathrm{~mL}$ sodium tartrate buffer $(50 \mathrm{mmol} / \mathrm{L}, \mathrm{pH}=4.5), 500 \mu \mathrm{L}$ Azure B (32 $\mu \mathrm{mol} / \mathrm{L}), 500 \mu \mathrm{L}$ enzyme filtrate and $500 \mu \mathrm{L} \mathrm{H}_{2} \mathrm{O}_{2}(400 \mu \mathrm{mol} / \mathrm{L})$. The reaction was initiated by the addition of $\mathrm{H}_{2} \mathrm{O}_{2}$. The absorbance decrease was measured against distilled water. The molar absorption coefficient of oxidized Azure B of $\varepsilon_{651 \mathrm{~nm}}=48.8$ $\mathrm{L} /(\mathrm{mmol} \cdot \mathrm{cm})(25)$ was used for enzyme activity calculation.

\section{Molecular identification of selected isolates}

\section{DNA extraction and PCR amplification}

Fungal DNA was extracted from fresh samples. Pieces of actively growing mycelia, approx. $2.5-3 \mathrm{~mm}$ in diameter, were pulled out from 7-day-old fungal cultures grown on mineral agar medium of the same composition as cellulase basal medium suggested by Pointing (20) but with $\mathrm{NH}_{4} \mathrm{NO}_{3}$ instead of ammonium tartrate. They were aseptically cleaned from mineral agar and transferred to Eppendorf tubes filled with $700 \mu \mathrm{L}$ of sterile mineral broth of the same composition as agar medium. This substrate proved to be suitable for rapid increase in the biomass of isolated fungi. Fungi were incubated for 3 days at $30^{\circ} \mathrm{C}$ in the dark. Prior to DNA extraction, the samples were pelleted in a microcentrifuge (MiniSpin ${ }^{\circledR}$, max. speed of $12100 \times g$; Eppendorf, Hamburg, Germany), at (25 \pm 2 ) ${ }^{\circ} \mathrm{C}$ and $4313 \times g$ for $3 \mathrm{~min}$, after which the mineral medium was discarded. This step was repeated twice, and then the samples were washed with $500 \mu \mathrm{L}$ of $0.1 \times$ TE (Tris-EDTA) buffer $(\mathrm{pH}=8)$, and pelleted in the microcentrifuge (MiniSpin ${ }^{\circledR}$ ) at $4313 \times g$ in order to remove the residual mineral broth. This step was also repeated twice; the first cycle lasted $5 \mathrm{~min}$, the second $3 \mathrm{~min}$. Prepared samples were resuspended in $2 \times$ CTAB lysis buffer prepared according to Gardes and Bruns (27). The buffer-suspended samples were frozen in the freezer at $-20^{\circ} \mathrm{C}$ for $15 \mathrm{~min}$ (instead of in dry ice) and thawed at $65^{\circ} \mathrm{C}$ in heated blocs for $15 \mathrm{~min}$. The cycles of freezing and thawing were repeated three times. All subsequent steps of DNA extraction were the same as in a protocol proposed by Gardes and Bruns (27).

For PCR amplification of internal transcribed spacer (ITS) region of the ribosomal DNA, a primer set ITS1/ITS4 was used (28). The extracted total DNA served as a template. The 50$-\mu \mathrm{L}$ reaction mixture contained: $1 \mu \mathrm{L}$ of DNA template, $1 \mu \mathrm{L}$ $10 \mu \mathrm{mol} / \mathrm{L}$ forward primer (ITS1: 5'-TCCGTAGGTGAACCTGCGG-3'), $1 \mu \mathrm{L} 10 \mu \mathrm{mol} / \mathrm{L}$ reverse primer (ITS4: 5'-TCCTCCGCTTATTGATATGC-3'), $25 \mu \mathrm{L} 2 \times$ PCR LongNova-RED Master Mix (DNA GDAŃSK, Blirt S.A., Gdańsk, Poland) and $22 \mu \mathrm{L}$ ultrapure distilled water. The PCR amplification was performed in QB24 Thermal Cycler (Quanta Biotech Ltd., Byfleet, UK). The temperature parameters were set as follows: $15 \mathrm{~min}$ at $95^{\circ} \mathrm{C}$ for initial denaturation, 30 cycles of denaturation step (30 s at 95 ${ }^{\circ} \mathrm{C}$ ), annealing step $\left(30 \mathrm{~s}\right.$ at $55^{\circ} \mathrm{C}$ ) and elongation step (90 s at $\left.72^{\circ} \mathrm{C}\right)$, and 5 min at $72^{\circ} \mathrm{C}$ for final extension.

\section{DNA sequencing and identification}

The PCR products of selected fungi were examined by agarose gel electrophoresis (MultiSUB Horizontal Gel Systems, Cleaver Scientific Ltd., Rugby, UK). Ethidium bromide was used for DNA visualization. The sequencing of PCR products was performed by Macrogen sequencing service (Macrogen Inc., Amsterdam, the Netherlands). The obtained sequences were compared with the National Center for Biotechnology Information (NCBI) GenBank database $(29,30)$. Sequences were deposited to GenBank with the accession numbers KY264754 for isolate F13 and KY264753 for isolate F28. Phylogenetic and molecular evolutionary analyses were conducted using MEGA software v. 5 (31).

\section{Determination of protein concentration and mass fraction}

Protein concentration was determined by Lowry method using bovine serum albumin as a standard (32). The amount of protein generated per unit of dry substrate mass (mass fraction) is calculated according to the formula:

$$
w_{\mathrm{m}}=\left(\gamma \cdot V_{\mathrm{ex}}\right) / m_{\mathrm{s}}
$$

where $w_{m}$ is protein mass fraction in dry substrate $(\mathrm{mg} / \mathrm{g}), \gamma$ is protein concentration obtained by Lowry method $(\mathrm{mg} / \mathrm{mL})$, $V_{\text {ex }}$ is total volume of extracted enzymes $(\mathrm{mL})$, and $m_{\mathrm{s}}$ is dry mass of the substrate $(\mathrm{g})$. 


\section{Determination of total solids and lignin content}

Total solids in biomass were determined according to NREL/TP-510-42621 report (33). Acid-soluble lignin (ASL) and acid-insoluble lignin (AIL) were determined according to Laboratory analytical procedures LAP-004 and LAP-003 $(34,35)$. ASL was calculated using the absorbance of hydrolysate measured at $205 \mathrm{~nm}$ and the molar absorption coefficient of $110 \mathrm{~L} /(\mathrm{g} \cdot \mathrm{cm})$.

\section{Statistical analysis}

All values are expressed as mean \pm standard deviation. Mean values were compared using analysis of variance (ANOVA). The impact of cultivation conditions on the fungal ability to produce adequate enzyme activity was evaluated by two-way ANOVA. Welch's ANOVA followed by Tukey's honestly significant difference (HSD) test was applied for evaluation of differences among fungi on the basis of their enzyme activity under specific cultivation conditions. Two-sample $t$-test was used for evaluation of maximal activities obtained on SSdS and LMS. Differences were considered significant at $\mathrm{p}<0.05$. Statistical analyses were done using RStudio v. 1.0.136 (36).

\section{RESULTS AND DISCUSSION}

\section{Identification of isolated fungi}

The two isolates, F13 and F28, were subjected to identification by morphological and molecular characteristics (Table 2). Phylogenetic analysis was also performed (Fig. 1). The identities greater than $98 \%$ with query cover higher than $95 \%$ in the NCBI BLAST search (37) were considered as species-level identification.

Table 2. Data of strains/isolates with the highest similarity to F13 and F28 isolates, and obtained identities

\begin{tabular}{|c|c|c|c|c|}
\hline \multirow[b]{2}{*}{ Identified isolate } & \multirow[b]{2}{*}{ GenBank accession number } & \multicolumn{3}{|c|}{ Molecular identification by BLAST algorithm } \\
\hline & & $\begin{array}{l}\text { Fungal strain/isolate } \\
\text { (accession number) }\end{array}$ & $\begin{array}{c}\text { Query } \\
\text { cover } / \%\end{array}$ & Identity/\% \\
\hline \multirow[t]{4}{*}{ Trametes hirsuta isolate F13 } & KY264754 & T. hirsuta strain 394 (KC920740) & 100 & 100 \\
\hline & & T. hirsuta strain FCL21 (JF308949) & 100 & 99 \\
\hline & & T. hirsuta strain NBRC 7038 (AB733170) & 100 & 99 \\
\hline & & T. villosa voucher FP86588sp (JN164970) & 97 & 99 \\
\hline \multirow[t]{8}{*}{ Stereum gausapatum isolate F28 } & KY264753 & S. hirsutum isolate BC (KR909200) & 100 & 99 \\
\hline & & S. hirsutum isolate oak16 (FN539063) & 100 & 99 \\
\hline & & S. hirsutum strain BS7 (KP985742) & 100 & 99 \\
\hline & & S. gausapatum (KF897020) & 99 & 99 \\
\hline & & S. gausapatum isolate st69 (FN539048) & 96 & 99 \\
\hline & & S. rugosum (KX218390) & 90 & 99 \\
\hline & & S. sanguinolentum isolate Fp-102551 (AY089730) & 97 & 96 \\
\hline & & $\begin{array}{l}\text { S. complicatum voucher CFMR:DLL2011-039 } \\
\text { (KJ140563) }\end{array}$ & 94 & 96 \\
\hline
\end{tabular}

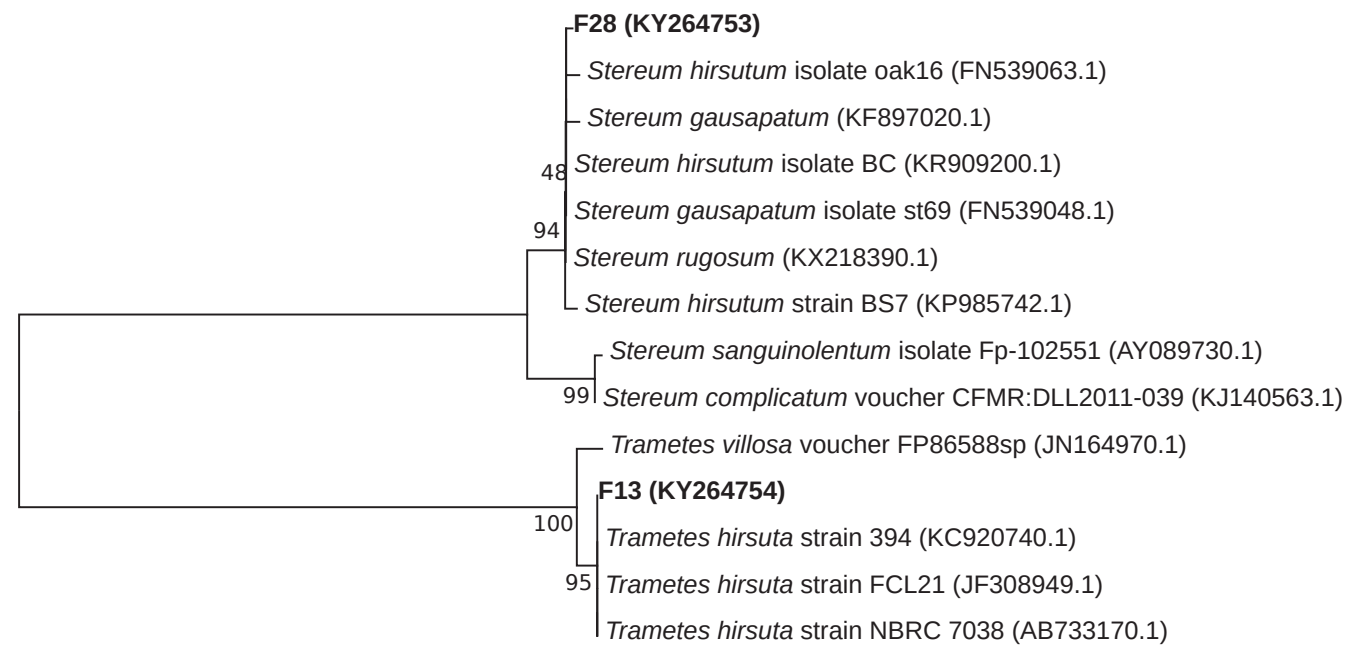

Fig. 1. Comparative phylogenetic analysis of the two selected fungi with closely related strains/isolates based on internal transcribed spacer (ITS) sequences. Parameters used for neighbor-joining tree construction: Tamura-Nei model (31), test of phylogeny by the bootstrap method, 1000 bootstrap replications. Accession numbers from NCBI (30) database of each strain/isolate are in brackets 
The internal transcribed spacer (ITS) sequence of F13 showed the highest identity level with the strain Trametes hirsuta 394 (Table 2). For F28, the ITS sequence was $99 \%$ identical with the ITS sequences of two species that belong to Stereum hirsutum complex: S. hirsutum and S. gausapatum with 100 and $99 \%$ query cover, respectively. Fungi from $S$. hirsutum complex which includes S. hirsutum, S. complicatum, S. styracifluum, S. subtomentosum, S. versicolor and S. gausapatum are hard to distinguish from one another only according to the morphological characteristics. Some mycologists consider them as varieties of S. hirsutum (38). A few research articles have been published in order to help in differentiating S. gausapatum from S. hirsutum $(39,40)$. According to molecular, morphological and phylogenetic analyses, we concluded that the F28 isolate should be identified as S. gausapatum. Both isolates belong to phylum Basidiomycota, which includes the most efficient lignin decomposers in nature.

\section{Screening for ligninolytic enzyme activity of the fungal isolates}

\section{Qualitative assays}

Laccase activity was assayed using guaiacol and a-naphthol as reagents. Both isolates were able to oxidize these reagents; colour zones appeared within $24 \mathrm{~h}$ of cultivation. Isolated fungi were also tested for LiP activity by Azure B qualitative assay $(20,25)$. The presence of discolouration zones under or around mycelium is a proof of LiP activity, and positive results were detected only in the case of S. gausapatum F28. The discolouration zones were present only under the mycelia. A percentage of the discoloured area was calculated three weeks after the inoculation. The obtained value was $10 \%$.

\section{Quantitative assays}

Impact of cultivation conditions (SF and SSF) on fungal ligninolytic abilities was examined by quantitative assays of enzyme activities. Both isolates were able to grow on lignocellulose substrate used in this study. Obtained activities are presented in Fig. 2.

Laccase activities are presented in Fig. 2a. Cultivation conditions had a significant impact on enzyme activities $(p<0.001)$. Laccase activities significantly differed among isolates, both under SF cultivation conditions $\left(F_{1,3.1}=3459.5\right.$, $\mathrm{p}<0.05)$ and under SSF cultivation conditions $\left(\mathrm{F}_{1,4}=1612.9\right.$, $\mathrm{p}<0.05)$. An interesting fact is that the value of $(315.9 \pm 0.7)$ $\mathrm{U} / \mathrm{L}$ recorded for the isolate $\mathrm{F} 13$ in SF was significantly higher than that recorded in SSF $(p<0.05)$, although the SSF activity was also very high ((71.2 \pm 0.5$) \mathrm{U} / \mathrm{L})$. The F28 laccase activities in SSF and SF also differed significantly ( $p<0.05)$, but unlike the F13, higher activities were recorded in SSF ((18.9 \pm 0.5$)$ $\mathrm{U} / \mathrm{L})$ than in SF ((14 \pm 1$) \mathrm{U} / \mathrm{L})$. To better explain the significance of these results, the laccase activities of isolates F13 and F28 were compared to the values of Trametes versicolor tested with different reagents (ABTS, 2,6-dimetoxyphenol, syringaldazine and guaiacol) according to Margot et al. (41). ABTS,
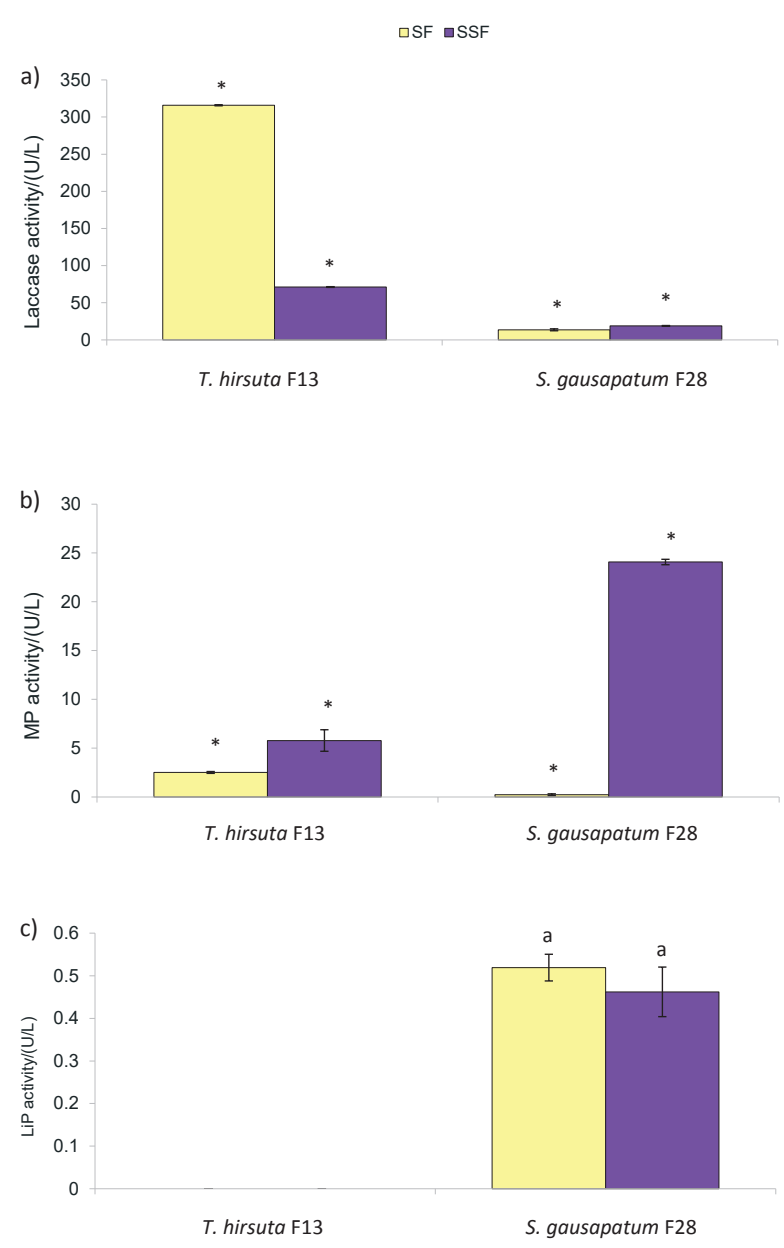

Fig. 2. Comparison of: a) laccase, b) manganese peroxidase (MP), and c) lignin peroxidase (LiP) activities obtained for fungal isolates Trametes hirsuta F13 and Stereum gausapatum F28 under different cultivation conditions: solid-state fermentation (SSF) and submerged fermentation (SF). Values are mean \pm standard deviation of at least three replicates. Statistically significant differences $(p<0.05)$ are labelled with an asterisk. Letter a indicates values that did not differ significantly $(p>0.05)$

2,6-dimetoxyphenol, syringaldazine and guaiacol are reagents suitable for testing the laccase activity, but all of them are of different sensitivity and, accordingly, the values of the measured enzymatic activities are of a different order of magnitude. This prevents direct comparison of laccase activities tested with different reagents. Published articles usually report laccase activities that are measured using one or sometimes two of those reagents, therefore, it is not always possible to compare the obtained results with the results from the literature. The comparative study conducted by Margot et al. (41) is one of the few studies that used all four reagents for detection and measurement of laccase activity, and T. versicolor belongs to the group of fungi with highly active ligninolytic enzymes, which makes it suitable for comparison. Laccase activity of isolates F13 and F28 was measured using guaiacol, while the experiments with $T$. hirsuta in the literature have 
mainly used ABTS or syringaldazine $(42,43)$. Guaiacol is the least sensitive reagent giving much lower laccase activity values than ABTS or syringaldazine. The use of the comparative study carried out with all of the above reagents helped to conclude that both isolates, F13 and F28, possess very high laccase activity, and qualify them as laccase-producing fungi with a potential for industrial use.

MP activity of both isolates was recorded (Fig. 2b). Cultivation conditions had a significant impact on the MP activities $(p<0.001)$; the obtained results showed that SSF was more suitable for MP production than SF. Measured values of MP activities also differed significantly among the isolates (in SSF cultivation $\mathrm{F}_{1,5.6}=1548.2, \mathrm{p}<0.05$ and in SF $\left.F_{1,10}=1753.9, p<0.05\right)$. In SSF isolate F28 showed the highest activity of $(24.1 \pm 0.3) \mathrm{U} / \mathrm{L}$, while the value for isolate $\mathrm{F} 13$ was $(6 \pm 1) \mathrm{U} / \mathrm{L}$. Activities measured in SF were lower than $3 \mathrm{U} / \mathrm{L}$, therefore we concluded that none of the isolates have the potential for use in submerged biotechnological applications that require MP activity. The SSF results qualify S. gausapatum F28 isolate as MP-producing fungus with a potential for industrial use.

It is usually difficult to detect LiP activity in extracts from natural lignocellulosic substrates used for ligninase production by fungi (44). The results of LiP activity are presented in Fig. 2c. S. gausapatum F28 was able to degrade high amount of Azure B in the qualitative assay, but in the quantitative assay, the obtained activities were lower than $1 \mathrm{U} / \mathrm{L}$. The impact of cultivation conditions was not statistically significant $\left(F_{1,3.07}=2.22, p>0.05\right)$. Because of low activities obtained in the screening process, LiP has not been studied further in this research.

Previous investigations have shown that T. hirsuta produces very active laccase $(45,46)$, which was also noted in this research. However, the F13 did not show LiP activity. Vasina et al. (42) analyzed the production of extracellular proteins by $T$. hirsuta 072 and also found that this fungus does not produce LiP, while it does produce MP and laccase. They also reported that the laccase is a predominant enzyme in the ligninolytic system of T. hirsuta, which could also be applicable for the isolate F13. Differently, S. gausapatum F28 showed laccase, MP and LiP activities. This is the first record of LiP activity for S. gausapatum, while laccase and MnP activities have been reported earlier (47).

\section{Effect of substrate moisture on ligninolytic enzyme activity}

In further study, the focus was on laccase and manganese peroxidase activities as main ligninolytic enzymes of selected isolates. Fig. 3 shows the effect of substrate moisture on laccase, MnP and VP activity of selected isolates. In SSF the moisture content can vary between 20 and $85 \%(48,49)$, although high laccase activities of fungi are often reported with the moisture content between 60 and $80 \%$ (50-52). In this research, the influence of initial moisture content on the ligninolytic activity of selected fungi was evaluated in the substrates with 68 and $75 \%$ moisture.
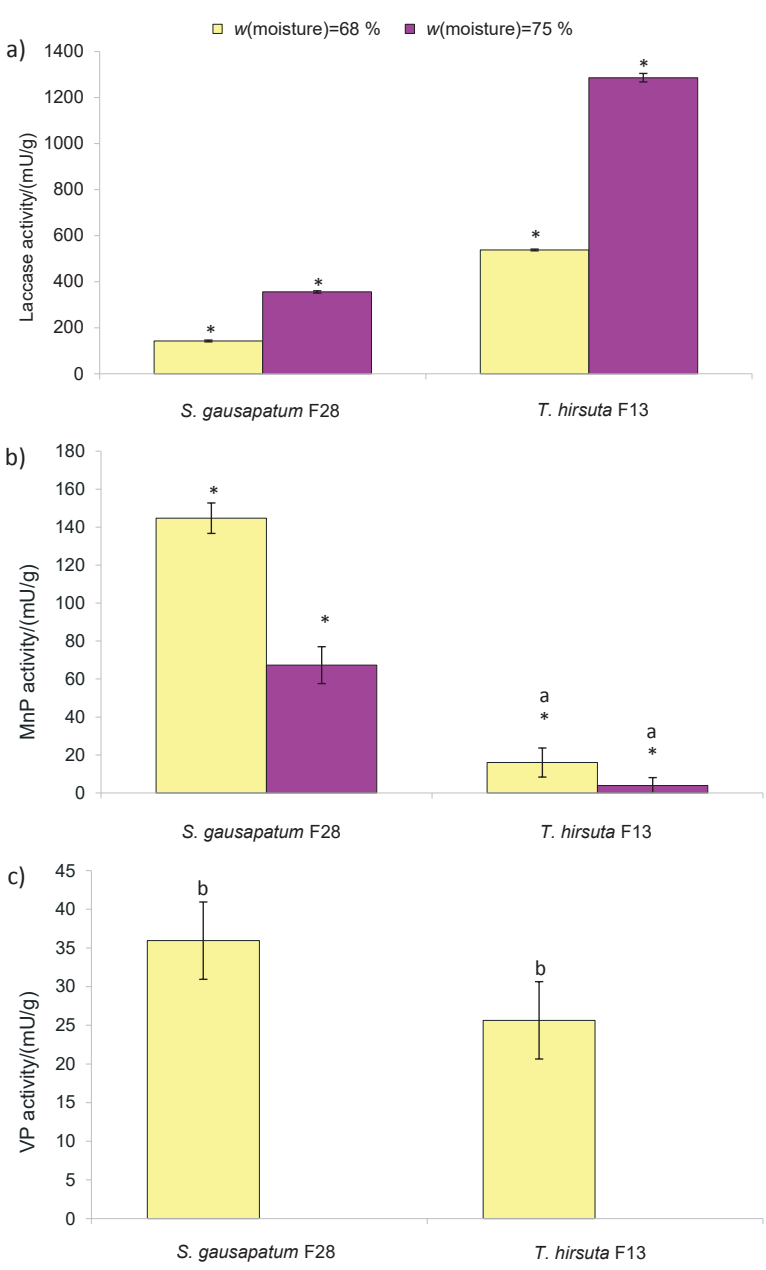

Fig. 3. Influence of substrate moisture content on ligninolytic enzyme activity of Trametes hirsuta isolate F13 and Stereum gausapatum isolate F28: a) laccase activity, b) manganese-dependent peroxidase $(\mathrm{MnP})$ activity, and c) versatile peroxidase (VP) activity. Values are mean \pm standard deviation of at least three replicates. Activities that differed significantly $(p<0.05)$ are marked with an asterisk. Letters a and $b$ denote activities that did not differ significantly $(p>0.05)$

As shown in Fig. 3a, higher values of laccase activity of T. hirsuta F13 and S. gausapatum F28 were measured in substrates with $75 \%$ moisture content than in those with $68 \%$. Differences were statistically significant $(p<0.05)$. Meehnian et al. (52) analyzed the effect of the moisture content and particle size on the ligninolytic activity of Daedalea flavida and recorded high laccase activity in the substrate with $75 \%$ moisture content ((4.26 \pm 0.38$) \mathrm{U} / \mathrm{g}$ assayed with ABTS). T. hirsuta F13 and S. gausapatum F28 also showed very high laccase activity with $75 \%$ moisture content, with the values of (1290 \pm 20$)$ and $(350 \pm 5) \mathrm{mU} / \mathrm{g}$, respectively.

The higher value of substrate moisture content stimulated laccase activity, but it had an opposite or no effect on the MnP activity, depending on the fungal isolate (Fig. 3b). Both isolates showed higher $\mathrm{MnP}$ activity on the substrate with $68 \%$ moisture content than with $75 \%$. Obtained differences were statistically significant for S. gausapatum F28 $(p<0.05)$, while for T. hirsuta F13 they were not ( $p>0.05)$. 
The moisture content also influenced VP activity. While the VP activities of (35 \pm 7 ) $\mathrm{mU} / \mathrm{g}$ for S. gausapatum F28 and (26 \pm 3$) \mathrm{mU} / \mathrm{g}$ for T. hirsuta F13 were observable with $68 \%$ moisture content, with $75 \%$ substrate moisture the VP activity was not detectable (Fig. 3c).

\section{Time course of enzyme activity and protein production}

The activities obtained by two selected fungi on SSdS were compared to those obtained on LMS. Production of enzymes was carried out under SSF with $75 \%$ moisture content, which provides very high values of laccase activity, as previously shown. This part of the research was conducted in order to determine the ability of selected isolates to grow and produce ligninolytic enzymes on a simple substrate, so that could later be used in the delignification of lignocellulosic waste. Depending on the species, cultivation conditions and incubation time, the ligninase activity may vary significantly (24). Table 3 shows that the enzyme activities varied depending on the day of incubation, and the addition of minerals had a significant impact on that dependence $(p<0.001)$.

Both isolates were able to produce very high laccase activity on SSdS. Activities significantly differed depending on the day of incubation (Table 3). T. hirsuta F13 achieved maximum laccase activities of (1324 \pm 7 ) $\mathrm{mU} / \mathrm{g}$ on LMS and (830 \pm 5 ) $\mathrm{mU} / \mathrm{g}$ on SSdS after ten days of incubation. The difference was significant $(p<0.05)$, but SSdS activity was also extremely high. S. gausapatum F28 expressed the maximum activity on LMS on the tenth day of incubation $((355 \pm 5) \mathrm{mU} / \mathrm{g})$, and on SSdS on the fifth day of incubation $((144.4 \pm 0.8) \mathrm{mU} / \mathrm{g})$.

As expected, higher MnP activities were obtained with S. gausapatum F28 than with T. hirsuta F13. Activities differed significantly depending on the day of incubation (Table 3 ).

Table 3. Enzyme activity and protein production per dry substrate mass and specific activity obtained on lignocellulose-mineral substrate (LMS) and simple solid substrate (SSdS) by selected isolates

\begin{tabular}{|c|c|c|c|c|c|c|}
\hline \multirow{3}{*}{ Enzyme } & \multirow{3}{*}{ Isolate } & \multirow{3}{*}{ Substrate } & \multicolumn{4}{|c|}{$t$ (incubation)/day } \\
\hline & & & 3 & 5 & 7 & 10 \\
\hline & & & \multicolumn{4}{|c|}{ Activity/(mU/g of solid substrate) } \\
\hline \multirow{4}{*}{ Laccase } & \multirow{2}{*}{ T. hirsuta F13 } & LMS & $481 \pm 1$ & $1120 \pm 50$ & $(1290 \pm 20)^{\mathrm{e}}$ & $(1324 \pm 7)^{\mathrm{e}}$ \\
\hline & & SSdS & $(389.2 \pm 0.8)^{\mathrm{a}}$ & $621 \pm 1$ & $(815 \pm 5)^{d}$ & $(830 \pm 5)^{d}$ \\
\hline & \multirow{2}{*}{ S. gausapatum F28 } & LMS & $(137 \pm 3)^{b}$ & $252 \pm 5$ & $(356 \pm 7)^{a}$ & $(355 \pm 5)^{\mathrm{a}}$ \\
\hline & & SSdS & $(104.4 \pm 0.8)^{\mathrm{bc}}$ & $(144.4 \pm 0.8)^{\mathrm{b}}$ & $(74 \pm 1)^{c}$ & $(63 \pm 1)^{c}$ \\
\hline \multirow{4}{*}{$\mathrm{MnP}$} & \multirow{2}{*}{ T. hirsuta F13 } & LMS & - & $(6 \pm 1)^{\mathrm{a}}$ & - & $(1.37 \pm 0.01)^{\mathrm{a}}$ \\
\hline & & SSdS & $(12 \pm 1)^{a}$ & $(8 \pm 2)^{\mathrm{a}}$ & $(8.7 \pm 0.2)^{\mathrm{a}}$ & $(12 \pm 1)^{\mathrm{a}}$ \\
\hline & \multirow{2}{*}{ S. gausapatum F28 } & LMS & $(6.18 \pm 0.01)^{\mathrm{a}}$ & $(27.8 \pm 0.5)^{\mathrm{b}}$ & $67 \pm 9$ & $(3.4 \pm 0.1)^{\mathrm{a}}$ \\
\hline & & SSdS & $(5.8 \pm 0.5)^{\mathrm{a}}$ & $(25 \pm 1)^{\mathrm{bc}}$ & $39 \pm 1$ & $(20.3 \pm 0.5)^{c}$ \\
\hline \multirow{9}{*}{ VP } & \multirow{2}{*}{ T. hirsuta F13 } & LMS & $6 \pm 1$ & - & - & - \\
\hline & & SSdS & - & $8 \pm 2$ & - & - \\
\hline & \multirow{2}{*}{ S. gausapatum F28 } & LMS & - & - & - & - \\
\hline & & SSdS & - & - & - & - \\
\hline & & & \multicolumn{4}{|c|}{$w($ protein $) /(\mathrm{mg} / \mathrm{g})$} \\
\hline & \multirow{2}{*}{ T. hirsuta F13 } & LMS & $2.0 \pm 0.2$ & $2.2 \pm 0.2$ & $2.6 \pm 0.4$ & $2.8 \pm 0.6$ \\
\hline & & SSdS & $2.4 \pm 0.2$ & $2.4 \pm 0.7$ & $(4.2 \pm 0.4)^{*}$ & $2.7 \pm 0.3$ \\
\hline & \multirow{2}{*}{ S. gausapatum F28 } & LMS & $3.3 \pm 0.4$ & $2.8 \pm 0.1$ & $2.5 \pm 0.2$ & $3.5 \pm 0.1$ \\
\hline & & SSdS & $(3.9 \pm 0.2)^{*}$ & $3.2 \pm 0.2$ & $(5.9 \pm 0.4)^{*}$ & $(4.2 \pm 0.2)^{*}$ \\
\hline & & & \multicolumn{4}{|c|}{ Activity/(mU/mg of protein) } \\
\hline \multirow{4}{*}{ Laccase } & \multirow{2}{*}{ T. hirsuta F13 } & LMS & $(150 \pm 20)^{\mathrm{a}}$ & $(410 \pm 20)^{d}$ & $510 \pm 30$ & $(380 \pm 10)^{d}$ \\
\hline & & SSdS & $(99 \pm 5)^{\mathrm{e}}$ & $190 \pm 10$ & $(140 \pm 10)^{\mathrm{a}}$ & $197 \pm 9$ \\
\hline & \multirow{2}{*}{ S. gausapatum F28 } & LMS & $(41 \pm 5)^{\mathrm{b}}$ & $(91 \pm 4)^{\mathrm{e}}$ & $(141 \pm 9)^{\mathrm{a}}$ & $(101 \pm 4)^{\mathrm{e}}$ \\
\hline & & SSdS & $(27 \pm 1)^{c}$ & $(45 \pm 2)^{b}$ & $(12.4 \pm 0.8)^{c}$ & $(15.0 \pm 0.7)^{c}$ \\
\hline \multirow{4}{*}{$\mathrm{MnP}$} & \multirow{2}{*}{ T. hirsuta F13 } & LMS & - & $(2.11 \pm 0.09)^{\mathrm{a}}$ & - & $(0.39 \pm 0.01)^{\mathrm{a}}$ \\
\hline & & SSdS & $(3.0 \pm 0.1)^{\mathrm{a}}$ & $(2.6 \pm 0.1)^{\mathrm{a}}$ & $(1.46 \pm 0.09)^{\mathrm{a}}$ & $(2.9 \pm 0.1)^{\mathrm{a}}$ \\
\hline & \multirow{2}{*}{ S. gausapatum F28 } & LMS & $(1.9 \pm 0.2)^{a}$ & $(10.0 \pm 0.4)^{b}$ & $27 \pm 2$ & $(0.97 \pm 0.03)^{\mathrm{a}}$ \\
\hline & & SSdS & $(1.48 \pm 0.07)^{a}$ & $(7.8 \pm 0.4)^{\mathrm{cb}}$ & $(6.5 \pm 0.4)^{c}$ & $(4.8 \pm 0.2)^{\mathrm{ac}}$ \\
\hline \multirow{4}{*}{ VP } & \multirow{2}{*}{ T. hirsuta F13 } & LMS & $1.8 \pm 0.2$ & - & - & - \\
\hline & & SSdS & - & $2.3 \pm 0.1$ & - & - \\
\hline & \multirow{2}{*}{ S. gausapatum F28 } & LMS & - & - & - & - \\
\hline & & SSdS & - & - & - & - \\
\hline
\end{tabular}

*The measured values of protein mass fractions that are significantly different from the others $(p<0.05)$. Differences among activity values obtained for a particular enzyme were statistically significant $(p<0.05)$. The same letter in superscript denotes values that do not differ significantly. $\mathrm{MnP}=$ manganese-dependent peroxidase, $\mathrm{VP}=$ versatile peroxidase 
Strain F28 achieved maximum activity after seven days of incubation on both substrates. Higher values were obtained on LMS ((67 \pm 9$) \mathrm{mU} / \mathrm{g})$ than on SSdS ((39 \pm 1$) \mathrm{mU} / \mathrm{g})$; differences were statistically significant $(p<0.05)$ but the obtained values indicated the ability of S. gausapatum F28 to produce high $\mathrm{MnP}$ activity on simple lignocellulosic substrate, which can be improved by the adjustment of appropriate conditions. T. hirsuta F13 showed better results on SSdS, although all obtained $\mathrm{MnP}$ activities were rather low (Table 3). The VP activity was not noticeable during any of the incubation days of S. gausapatum F28, which could be related to the inadequate moisture content since previous tests showed its ability to produce VP on a substrate with $68 \%$ moisture content. The VP activities of T. hirsuta F13 were observable on the third day of incubation on LMS $((6 \pm 1) \mathrm{mU} / \mathrm{g})$ and on the fifth day of incubation on SSdS ((8 82$) \mathrm{mU} / \mathrm{g})$.

Actual protein mass fractions during incubation served to calculate and compare the specific enzyme activities. Table 3 gives protein mass fractions and specific activities. Specific enzyme activity is a measure of enzyme purity. Higher activity with lower protein mass fraction means that during the enzyme production lower mass fractions of undesirable proteins are produced. In this research, cultivation on LMS gave better results. LMS gave significantly higher enzyme activities $(p<0.05)$, while SSdS produced much higher protein mass fractions. These results showed that the addition of minerals to media can improve product quality if their purpose is for enzyme production. However, the maximal specific laccase activities of (197 \pm 9$)$ and $(45 \pm 2) \mathrm{mU} / \mathrm{mg}$, and MnP activities of (3.0 \pm 0.1$)$ and (7.8 \pm 0.4$) \mathrm{mU} / \mathrm{mg}$ of T. hirsuta F13 and S. gausapatum F28, respectively, on SSdS confirmed that these two fungi are good source of highly active ligninolytic enzymes and that both could be used for lignin removal from lignocellulosic waste. The lignin removal was subsequently examined in this work.

\section{Biomass reduction and lignin removal}

In this research, delignification of lignocellulosic material by two selected isolates was examined on beech wood sawdust. Beech wood sawdust is a waste from wood processing and forestry industry that is widely available and cheap in Serbia. This substrate contains small particles, and its preparation does not require additional time and energy. Also, it acts as an inducer of ligninolytic enzymes such as laccase (53). Substrates were separately inoculated with isolates F13 and F28 and incubated for 35 days in the dark at $30^{\circ} \mathrm{C}$. A share of remaining lignin and lignocellulosic substrate determined before and after biological treatment is presented in Fig. 4.

T. hirsuta and S. gausapatum are saprophytic fungi that belong to a group of white-rot fungi. This group includes fungi able to decompose lignocellulose selectively by degrading lignin rather than holocellulose and fungi that degrade lignocellulose non-selectively by simultaneous removal of lignin and holocellulose. A selective degradation by T. hirsuta has already been reported (43). This type of lignin removal

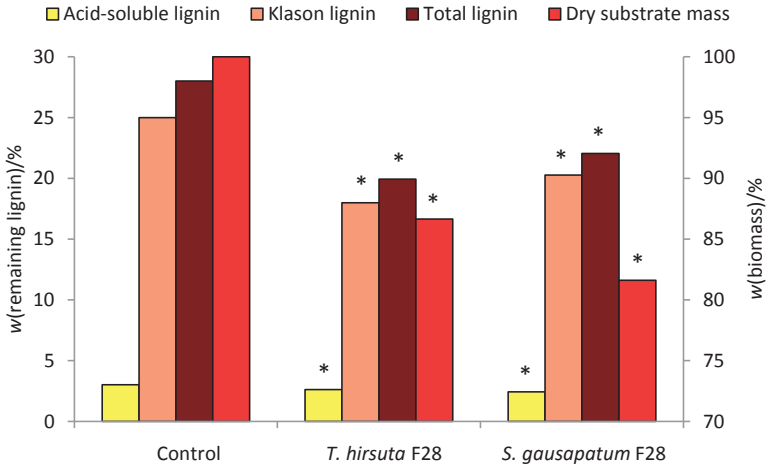

Fig. 4. Lignin removal and substrate reduction by selected fungi. The bar chart represents the percentage of remaining dry mass of the dry substrate, Klason lignin, acid-soluble lignin and total lignin mass fractions before and after pretreatment. Asterisk indicates statistically significant differences $(p<0.05)$ between the remaining lignin (lignin mass after pretreatment) and control (initial lignin mass) and remaining lignocellulosic biomass and control. All values are calculated relative to the initial biomass

is preferable for pretreatment of lignocellulosic substrates since it preserves higher amounts of holocellulose. Ligninolytic abilities of S. gausapatum have not been examined before, although the studies of dead wood from which fungi were collected have shown that $S$. gausapatum causes simultaneous white rotting (54). As a primary colonizer of oak branches, S. gausapatum is expected to possess good ligninolytic abilities (55).

Isolates F13 and F28 reduced the amount of lignocellulosic biomass. A loss of $19 \%$ was recorded for T. hirsuta F13 and $24 \%$ for S. gausapatum F28. Reduction of initial biomass was statistically significant $(p<0.05)$. Despite the fact that $S$. gausapatum F28 reduced more biomass than T. hirsuta F13, the difference was not statistically significant ( $p>0.05$ ). As expected, both isolates were able to degrade lignin. Total lignin reduction was significant $(\mathrm{p}<0.05)$. Total lignin loss obtained with F13 was 33.8 and with F28 $28.8 \%$. T. hirsuta F13 better degraded Klason lignin ( $28 \%$ loss) than ASL (19\% loss). S. gausapatum F28 was able to degrade $19 \%$ of Klason lignin and $24 \%$ of ASL. Higher substrate reduction and lower lignin removal obtained with the isolate F28 were probably the result of higher holocellulose degradation. To analyze the efficiency of lignin removal it was necessary to compare selectivity indices. The index of selectivity was calculated as a ratio of total lignin loss to total mass loss $\left(m_{\mathrm{L}} / m_{\mathrm{t}}\right)$. The higher index was obtained for T. hirsuta F13 (1.7) than for S. gausapatum F28 (1.1), which indicated higher selectivity in the decomposition of the lignocellulosic substrate. According to Liers et al. (44), $\mathrm{m}_{\mathrm{L}} / \mathrm{m}_{\mathrm{t}}$ ratio between 1.0 and 1.9 indicates the high efficiency of lignin removal. The comparison of this with the results obtained with the selected isolates leads to a conclusion that $T$. hirsuta F13 and S. gausapatum F28 showed high efficiency of lignin degradation. Fukasawa et al. (56) tested decomposition of Japanese beech wood by diverse fungi, and obtained a selectivity of 1.0 for T. hirsuta, while we obtained much higher selectivity in this research. Lignin loss obtained here shows 
that S. gausapatum F28 is less selective degrader than T. hirsuta F13, but results of ligninolytic enzyme activities, primarily on the impact of humidity on enzyme activities, indicate that the adjustment of appropriate parameters can improve selectivity.

\section{CONCLUSIONS}

We examined two novel fungal isolates able to efficiently degrade lignin. Trametes hirsuta F13 exhibited higher selectivity than Stereum gausapatum F28. The substrate moisture content, the presence of additional minerals and cultivation conditions (solid-state fermentation or submerged fermentation) had a significant influence on the type and values of fungal ligninolytic enzyme activities, especially for S. gausapatum F28. This implies that a correct set of parameters could improve the selectivity of lignin removal by isolate F28. In this research, we have observed lignin peroxidase activity of S. gausapatum for the first time as well as demonstrated its ability to efficiently remove lignin. The SSF proved to be more suitable for the production of ligninolytic enzymes due to its similarity to the natural environment of fungi. Contrary to that, we obtained significantly higher values of laccase activity with T. hirsuta F13 in SF than in SSF. This fungus has extremely high laccase activity in general, but the fact that SF suits it better for laccase production indicates that it is a good candidate for submerged fermentation, which is commonly used in industry. In contrast, $S$. gausapatum F28 preferred the SSF. The obtained specific activities and protein mass fractions have shown that the addition of minerals to the substrate can improve product quality. After five weeks of incubation on beech wood sawdust, lignin losses were $33.84 \%$ with T. hirsuta F13 and $28.8 \%$ with S. gausapatum F28. The study revealed two fungal isolates capable of efficient lignin removal and as good sources for the production of industrially valuable enzymes. They both showed the potential for applications in various biotechnological fields.

\section{FUDING SOURCE}

This research is part of PhD thesis of the first author and did not receive any specific grant from funding agencies in the public, commercial, or not-for-profit sectors.

\section{REFERENCES}

1. Tiwari P, Misra BN, Sangwan NS. $\beta$-Glucosidases from the fungus Trichoderma: An efficient cellulase machinery in biotechnological applications. Biomed Res Int. 2013;2013: Article ID 203735.

https://doi.org/10.1155/2013/203735

2. Jönsson LJ, Martín C. Pretreatment of lignocellulose: Formation of inhibitory by-products and strategies for minimizing their effects. Bioresour Technol. 2016;199:103-12.

https://doi.org/10.1016/j.biortech.2015.10.009

3. Taherzadeh MJ, Karimi K. Pretreatment of lignocellulosic wastes to improve ethanol and biogas production: A review. Int J Mol Sci. 2008;9(9):1621-51.

https://doi.org/10.3390/ijms9091621

4. Kapoor A, Viraraghavan T, Cullimore DR. Removal of heavy metals using the fungus Aspergillus niger. Bioresour Technol. 1999;70(1):95-104.

https://doi.org/10.1016/S0960-8524(98)00192-8

5. Yan G, Viraraghavan T. Heavy-metal removal from aqueous solution by fungus Mucor rouxii. Water Res. 2003;37(18): 4486-96.

https://doi.org/10.1016/S0043-1354(03)00409-3

6. D'Annibale A, Rosetto F, Leonardi V, Federici F, Petruccioli $M$. Role of autochthonous filamentous fungi in bioremediation of a soil historically contaminated with aromatic hydrocarbons. Appl Environ Microbiol. 2006;72(1):28-36.

https://doi.org/10.1128/AEM.72.1.28-36.2006

7. Field JA, de Jong E, Feijoo Costa G, de Bont JA. Biodegradation of polycyclic aromatic hydrocarbons by new isolates of white rot fungi. Appl Environ Microbiol. 1992;58(7):221926.

8. Takada S, Nakamura M, Matsueda T, Kondo R, Sakai K. Degradation of polychlorinated dibenzo-p-dioxins and polychlorinated dibenzofurans by the white rot fungus Phanerochaete sordida YK-624. Appl Environ Microbiol. 1996;62 (12):4323-8.

9. Tigini V, Prigione V, Di Toro S, Fava F, Varese GC. Isolation and characterisation of polychlorinated biphenyl (PCB) degrading fungi from a historically contaminated soil. Microb Cell Factories. 2009;8:5.

https://doi.org/10.1186/1475-2859-8-5

10. Cerniglia CE, Sutherland JB. Degradation of polycyclic aromatic hydrocarbons by fungi. In: Timmis KN, editor. Handbook of hydrocarbon and lipid microbiology. Berlin, Germany: Springer; 2010. pp. 2079-110. https://doi.org/10.1007/978-3-540-77587-4_1511

11. Čvančarová M, Křesinová Z, Filipová A, Covino S, CajthamlT. Biodegradation of PCBs by ligninolytic fungi and characterization of the degradation products. Chemosphere. 2012; 88(11):1317-23.

https://doi.org/10.1016/j.chemosphere.2012.03.107

12. Pizzul L, Castillo MP, Stenström J. Degradation of glyphosate and other pesticides by ligninolytic enzymes. Biodegradation. 2009;20(6):751-9.

https://doi.org/10.1007/s10532-009-9263-1

13. Purnomo AS, Mori T, Kondo R. Involvement of Fenton reaction in DDT degradation by brown-rot fungi. Int Biodeterior Biodegrad. 2010;64(7):560-5. https://doi.org/10.1016/j.ibiod.2010.06.008

14. Ulčnik A, Kralj Cigić I, Pohleven F. Degradation of lindane and endosulfan by fungi, fungal and bacterial laccases. World J Microbiol Biotechnol. 2013;29(12):2239-47. https://doi.org/10.1007/s11274-013-1389-y 
15. Maza M, Pajot HF, Amoroso MJ, Yasem MG. Post-harvest sugarcane residue degradation by autochthonous fungi. Int Biodeterior Biodegrad. 2014;87:18-25.

https://doi.org/10.1016/j.ibiod.2013.10.020

16. Knežević A, Milovanović I, Stajić M, Lončar N, Brčeski I, Vukojević J, Ćilerdžić J. Lignin degradation by selected fungal species. Bioresour Technol. 2013;138:117-23.

https://doi.org/10.1016/j.biortech.2013.03.182

17. Knežević A, Milovanović I, Stajić M, Vukojević J. Potential of Trametes species to degrade lignin. Int Biodeterior Biodegrad. 2013;85:52-6. https://doi.org/10.1016/j.ibiod.2013.06.017

18. Knežević A, Stajić M, Vukojević J, Milovanović I. The effect of trace elements on wheat straw degradation by Trametes gibbosa. Int Biodeterior Biodegrad. 2014;96:152-6. https://doi.org/10.1016/j.ibiod.2014.10.004

19. Ćilerdžić J, Stajić M, Vukojević J. Activity of Mn-oxidizing peroxidases of Ganoderma lucidum depending on cultivation conditions. Bioresources. 2015;11(1):95-104. https://doi.org/10.15376/biores.11.1.95-104

20. Pointing SB. Qualitative methods for the determination of lignocellulolytic enzyme production by tropical fungi. Fungal Divers. 1999;2:17-33.

21. Chand P, Aruna A, Maqsood AM, Rao LV. Novel mutation method for increased cellulase production. J Appl Microbiol. 2005;98(2):318-23. https://doi.org/10.1111/j.1365-2672.2004.02453.x

22. Hosoya T.Turnip peroxidase: IV.The effect of $\mathrm{pH}$ and temperature upon the rate of reaction. J Biochem. 1960;48(2):17889. https://doi.org/10.1093/oxfordjournals.jbchem.a127158

23. Kuwahara M, Glenn JK, Morgan MA, Gold MH. Separation and characterization of two extracelluar $\mathrm{H}_{2} \mathrm{O}_{2}$-dependent oxidases from ligninolytic cultures of Phanerochaete chrysosporium. FEBS Lett. 1984;169(2):247-50. https://doi.org/10.1016/0014-5793(84)80327-0

24. Arora DS, Gill PK. Production of ligninolytic enzymes by Phlebia floridensis. World J Microbiol Biotechnol. 2005;21 (6-7):1021-8. https://doi.org/10.1007/s11274-004-7655-2

25. Archibald FS. A new assay for lignin-type peroxidases employing the dye azure B. Appl Environ Microbiol. 1992;58(9):3110-6.

26. Arora DS, Gill PK. Comparison of two assay procedures for lignin peroxidase. Enzyme Microb Technol. 2001;28(7-8): 602-5. https://doi.org/10.1016/S0141-0229(01)00302-7

27. Gardes M, Bruns TD. ITS primers with enhanced specificity for basidiomycetes-application to the identification of mycorrhizae and rusts. Mol Ecol. 1993;2(2):113-8. https://doi.org/10.1111/j.1365-294x.1993.tb00005.x
28. White TJ, Bruns T, Lee S, Taylor J. Amplification and direct sequencing of fungal ribosomal RNA genes for phylogenetics. In: PCR - Protocols and Applications - A laboratory manual. Cambridge, MA, USA: Academic Press, Inc 1990. pp. 31522. Available from: https://nature.berkeley.edu/brunslab/ papers/white1990.pdf.

29. Clark K, Karsch-Mizrachi I, Lipman DJ, Ostell J, Sayers EW. GenBank. Nucleic Acids Res. 2015;44(D1):D67-72. https://doi.org/10.1093/nar/gkv1276

30. NCBI Resource Coordinators. Database resources of the National Center for Biotechnology Information. Nucleic Acids Res. 2016;44(D1):D7-19.

https://doi.org/10.1093/nar/gkv1290

31. Tamura K, Peterson D, Peterson N, Stecher G, Nei M, Kumar S. MEGA5: Molecular evolutionary genetics analysis using maximum likelihood, evolutionary distance, and maximum parsimony methods. Mol Biol Evol. 2011;28(10):2731-9. https://doi.org/10.1093/molbev/msr121

32. Waterborg JH. The Lowry method for protein quantitation. In: Walker JM, editor. Protein protocols handbook. Totowa, NJ, USA: Humana Press; 2002. pp. 7-10. http://doi.org/10.1385/1-59259-169-8:7

33. Sluiter A, Hames B, Hyman D, Payne C, Ruiz R, Scarlata C, et al. Determination of total solids in biomass and total dissolved solids in liquid process samples. Technical Report NREL/TP-510-42621. Golden, CO, USA: National Renewable Energy Laboratory (NREL); 2008. Available from: http:// www.nrel.gov/docs/gen/fy08/42621.pdf.

34. Ehrman T. Determination of acid-soluble lignin in biomass. Chemical analysis and testing task, Laboratory analytical procedure LAP-004. Kansas City, MO, USA: National Renewable Energy Laboratory (NREL), Midwest Research Institute (MRI); 1996. Available from: http://infohouse.p2ric. org/ref/40/39121.pdf.

35. Templeton D, Ehrman T. Determination of acid-insoluble lignin in biomass. Chemical analysis and testing task, Laboratory analytical procedure LAP-003. Kansas City, MO, USA: National Renewable Energy Laboratory (NREL), Midwest Research Institute (MRI); 1995. Available from: http://infohouse.p2ric.org/ref/40/39122.pdf.

36. RStudio, v. 1.0.136. RStudio: Integrated development environment for R. Boston, MA, USA: RStudio, Inc; 2016. Available from: http://www.rstudio.com.

37. Altschul SF, Gish W, Miller W, Myers EW, Lipman DJ. Basic local alignment search tool. J Mol Biol. 1990;215(3):403-10. https://doi.org/10.1016/S0022-2836(05)80360-2

38. Tura D, Zmitrovich IV, Wasser SP, Nevo E. The genus Stereum in Israel. Mycotaxon. 2008;106:109-26.

39. Herrick JA. A Microscopical study of the mycelium of Stereum gausapatum Fries. Trans Am Microsc Soc. 1939;58(4): 377-84.

https://doi.org/10.2307/3222778 
40. Chamuris GP. On distinguishing Stereum gausapatum from the "S. hirsutum-complex." Mycotaxon. 1985;22:1-12.

41. Margot J, Bennati-Granier C, Maillard J, Blánquez P, Barry DA, Holliger C. Bacterial versus fungal laccase: Potential for micropollutant degradation. AMB Express. 2013;3:63. https://doi.org/10.1186/2191-0855-3-63

42. Vasina DV, Pavlov AR, Koroleva OV. Extracellular proteins of Trametes hirsuta st. 072 induced by copper ions and a lignocellulose substrate. BMC Microbiol. 2016;16(1):106. https://doi.org/10.1186/s12866-016-0729-0

43. Knežević A, Stajić M, Jovanović VM, Kovačević V, Ćilerdžić J, Milovanović I, Vukojević J. Induction of wheat straw delignification by Trametes species. Sci Rep. 2016;6:26529. https://doi.org/10.1038/srep26529

44. Liers C, Arnstadt T, Ullrich R, Hofrichter M. Patterns of lignin degradation and oxidative enzyme secretion by different wood- and litter-colonizing basidiomycetes and ascomycetes grown on beech-wood. FEMS Microbiol Ecol. 2011; 78(1):91-102.

https://doi.org/10.1111/j.1574-6941.2011.01144.x

45. Rodríguez Couto S, Rodríguez A, Paterson RRM, Lima N, Teixeira JA. Laccase activity from the fungus Trametes hirsuta using an air-lift bioreactor. Lett Appl Microbiol. 2006;42 (6):612-6. https://doi.org/10.1111/j.1472-765X.2006.01879.x

46. Liu J, Liu W, Cai Y, Liao X, Huang Q, Liang X. Laccase production by Trametes hirsuta, characterization, and its capability of decoloring chlorophyll. Pol J Microbiol. 2014;63(3):32333.

47. Hiscox J, Baldrian P, Rogers HJ, Boddy L. Changes in oxidative enzyme activity during interspecific mycelial interactions involving the white-rot fungus Trametes versicolor. Fungal Genet Biol. 2010;47(6):562-71. https://doi.org/10.1016/j.fgb.2010.03.007

48. Krishna C. Solid-state fermentation systems - An overview. Crit Rev Biotechnol. 2005;25(1-2):1-30. https://doi.org/10.1080/07388550590925383
49. Patel H, Gupte A. Optimization of different culture conditions for enhanced laccase production and its purification from Tricholoma giganteum AGHP. Bioresour Bioprocess. 2016;3:11.

https://doi.org/10.1186/s40643-016-0088-6

50. Aydınoğlu T, Sargın S. Production of laccase from Trametes versicolor by solid-state fermentation using olive leaves as a phenolic substrate. Bioprocess Biosyst Eng. 2013;36(2):215-22.

https://doi.org/10.1007/s00449-012-0777-2

51. Yasmeen Q, Asgher M, Sheikh MA, Nawaz H. Optimization of ligninolytic enzymes production through response surface methodology. Bioresources. 2013;8(1):944-68. https://doi.org/10.15376/biores.8.1.944-968

52. Meehnian H, Jana AK, Jana MM. Effect of particle size, moisture content, and supplements on selective pretreatment of cotton stalks by Daedalea flavida and enzymatic saccharification. 3 Biotech. 2016;6(2).

https://doi.org/10.1007/s13205-016-0548-x

53. Babič J, Pavko A. Enhanced enzyme production with the pelleted form of $D$. squalens in laboratory bioreactors using added natural lignin inducer. J Ind Microbiol Biotechnol. 2012;39(3):449-57.

https://doi.org/10.1007/s10295-011-1036-2

54. Ortiz R, Navarrete J, Oviedo C, Párraga M, Carrasco I, de la Vega $\mathrm{E}$, et al. White rot Basidiomycetes isolated from Chiloé National Park in Los Lagos region, Chile. Antonie Van Leeuwenhoek. 2013;104(6):1193-203.

https://doi.org/10.1007/s10482-013-0041-z

55. Boddy L, Bardsley DW, Gibbon OM. Fungal communities in attached ash branches. New Phytol. 1987;107(1):143-54. https://doi.org/10.1111/j.1469-8137.1987.tb04888.x

56. Fukasawa Y, Osono T, Takeda H. Decomposition of Japanese beech wood by diverse fungi isolated from a cool temperate deciduous forest. Mycoscience. 2005;46(2):97-101. https://doi.org/10.1007/S10267-004-0215-7 